\title{
Spor Bilimleri Fakültesi Öğrencilerinin İnsan Haklarına Yönelik Tutumları
}

\author{
Gül ÇAVUŞOĞLU ${ }^{1}$, Menderes KABADAYI ${ }^{1}$, Ali Kerim YILMAZ ${ }^{1}$ ve \\ Mehmet Yalçın TAŞMEKTEPLIGİL ${ }^{1}$
}

\section{Öz}

$\mathrm{Bu}$ çalışmanın amacı spor bilimleri fakültesinde eğitim gören öğrencilerin sporda insan haklarına ilişkin tutumlarının incelenmesidir. Çalş̧maya Ondokuz Mayıs Üniversitesi Spor Bilimleri Fakültesi, 2017-2018 öğretim yllı antrenörlük, spor yöneticiliği ve beden eğitimi öğretmenliği bölümü öğrencileri katılmıştır. Araştırma, gönüllü katılım ile yapılmıştır. Birinci sınıftan 79, ikinci sınıf 86, üçüncü sınıftan 121, dördüncü sınıftan 214, toplam 500 öğrenci araştırmaya katılmıştır. Verilerin toplanması amacıyla Sadık (2014) tarafından geliştirilen, 3 alt boyut ve 29 maddeden oluşan 'Sporda İnsan Hakları Tutum Ölçeği' kullanılmıştır. Normal dağılım gösteren gruplar için ANOVA testi ve t testi, normal dağılım göstermeyen gruplar için ise Mann Whitney U ve Kruskall Wallis $\mathrm{H}$ testleri uygulanmıştır. Sporda insan hakları alt boyutları için alınan skorlar 1. ve 2. sınıflar için daha düşük olup 3 ve 4 . sınıflar için daha yüksek çıkmıştır. Ayrıca yaş grubu arttıkça alınan skorların arttığı sonucuna varılmıştır. En düşük skora sahip yaş grubunun en düşük yaş aralığına sahip olan 18 ve 20 yaş arası grup olduğu görülmüştür. Sonuç olarak bu çalışmada sporcu üniversite öğrencilerinin kişilik hakları, sosyal haklar ve dayanışma hakları alt boyutlarına yönelik tutumları saptanmıștır. Spor bilimleri fakültesi öğrencilerinin sosyal haklar alt boyutu ortalamasının kişisel haklar ve dayanıșma hakları alt boyutu ortalamasına oranla daha yüksek olmasına rağmen sporda insan haklarına ilişkin genel tutumlarının düșük olduğu görülmüş̧ür. Buna göre, insan hakları konusunda Türkiye'de yapılması gereken birçok sosyal ve eğitime yönelik düzenlemeye ihtiyaç olduğu ortaya çıkmıştır.

Anabtar Kelimeler: İnsan Hakları, Spor Bilimleri, Tutum

\section{Attitudes of Sport Sciences Faculty Students about Human Rights}

\section{Abstract}

The purpose of this study is to examine the attitudes of students studying in the Faculty of Sport Sciences regarding human rights in sport. Students of the coaching education, sport management and physical education teaching departments participated in the study in 2017-2018 academic year. The research was carried out with voluntary participation. 79 students from the first grade, 86 from the second grade, 121 from the third grade, 214 from the fourth grade. A total of 500 students participated in the research. The "Human Rights Attitude Scale in Sports", which was developed by Sadık (2014) and consists of 3 sub-dimensions and 29 items, was used to collect data. ANOVA test and t test were used for groups with normal distribution, while Mann Whitney U and Kruskall Wallis $\mathrm{H}$ tests were used for groups without normal distribution. In sports, scores for human rights sub-dimensions were lower for $1 \mathrm{st}$ and 2 nd grades and higher for 3rd and 4th grades. In addition, it was concluded that as the age group increases, the scores obtained increase. The age group with the lowest score was found to be between the ages of 18 and 20 , with the lowest age range. As a conclusion, athlete university students' attitudes about the sub-dimensions of personal rights, social rights and solidarity rights were found in the present study. Although the students' average social rights sub-dimension scores were higher when compared with the averages of personal rights and solidarity rights, general attitude about human rights in sport were low. According to these results, it has been found that a great number of social and educational regulations are needed in Turkey about human rights.

Key Words: Human Rights, Sport Sciences, Attitude

\section{Atıf İçin / Please Cite As:}

Çavuşoğlu, G., Kabadayı, M., Yılmaz, A. K. ve Taşmektepligil, M. Y. (2020). Spor bilimleri fakültesi öğrencilerinin insan haklarına yönelik tutumları. Manas Sosyal Araştırmalar Dergisi, 9(1), 462-469.

Geliş Tarihi / Received Date: 13.02.2019

Kabul Tarihi / Accepted Date: 11.06.2019

\footnotetext{
${ }^{1}$ Dr. - Ondokuz Mayıs Üniversitesi, Yaşar Doğu Spor Bilimleri Fakültesi, gul.cavusoglu@omu.edu.tr ORCID: 0000-0001-8180-3945

${ }^{1}$ Doç. Dr. - Ondokuz Mayıs Üniversitesi, Yaşar Doğu Spor Bilimleri Fakültesi, menderes@omu.edu.tr ORCID: 0000-0002-4472-7485

${ }^{1}$ Dr. - Ondokuz Mayıs Üniversitesi, Yaşar Doğu Spor Bilimleri Fakültesi, alkrm_ylmz@hotmail.com ORCID: 0000-0002-0046-6711

1 Prof. Dr. - Ondokuz Mayıs Üniversitesi, Yaşar Doğu Spor Bilimleri Fakültesi, myalcin@gmail.com ORCID: 0000-0001-6542-7695
} 


\section{Giriş}

İnsan hakları, insanın sadece insan olması nedeniyle doğuştan sahip olduğu, onun kişiliğini ve değerlerini korumayı ve geliştirmeyi amaçlayan, üstün, evrensel ilke ve kurallar bütününe denir (Yiğittir, 2013). İnsan hakları, kişilerin sırf insan olmasından dolayı sahip oldukları temel hak ve özgürlüklerdir. Bütün insanlar din, dil, ırk, cinsiyet ayrımı olmaksızın bütün temel haklara sahiptir. Teknolojideki gelişmeler ve küreselleşmeye bağlı olarak dünyadaki toplumsal ilişkilerin yoğunlaşması, insanlar arasındaki iletişim ve etkileşimin mesafe sınırı olmaksızın şaşırtıcı bir şekilde gelişmesi, bireylere insan hak ve sorumluluk bilinci kazandırmanın önemini arttırmıştır (Karagözoğlu, 2017).

Temel insan hakları evrensel, bireysel, dokunulmaz, devredilmez ve vazgeçilmez nitelikleri taşımaktadır (Topsakal, 2017). Bu nedenle insan haklarına sahip herkes, insan olma sorumluluğunu taşımak ve insan olma koşullarını yerine getirmek durumundadır. İnsan hakları, her yaş, cinsiyet ve gelir grubu ile meslek ve eğitim aralığında bulunanları yakından ilgilendirir (Gül, 2013; Şahin, 2009; Berktay, 2004; Ünal, 1994; Kuçuradi, 2007; Yüksel, 2007). Günümüzde öne çıkan sosyal ve ekonomik haklar yönü (Tepe, 2009), insan olan herkes için; özellikle de eğitim kurumlarından okullarda 'insanlarla, öğrencilerle birlikte toplumun küçük birimini oluşturan okullar ile okul yaşamında bir şeyler yapan’ öğretmenler ve eğitim paydaşları için önemlidir (Aycan, 2002). Okul ortamında öğrenciler, sadece insan olmaları nedeniyle, arkadaşlarına ve okul çalışanlarına hosgörülü olmak, onların deneyimleriyle düşüncelerini sabırla dinlemek, onlara değer vermek, haklarına saygı göstermek durumundadır. Buna göre onlar, kendi haklarını da koruma yollarını öğrenirler (Kepenekçi, 2000; Meşeci, 2008; Memduhoğlu, 2008).

Dünyada yaşanan hak ihlalleri, uluslararası belgelerde yer alan kararların hayata yansımasının ancak bireylerin hak ve sorumluluk bilinci kazanmasiyla mümkün olabileceğini göstermektedir. Bireyin haklarının farkında olması, gerektiğinde uygun yol ve yöntemlerle savunabilmesi, başkalarının haklarını da gözetip savunabilmesi etkili insan hakları eğitimi ile gerçekleşebilecek kazanımlardır. İnsan hakları eğitimi, ailede başlayan ve toplumsal gelişme ve değişmelere paralel olarak hayat boyu devam etmesi gereken bir süreçtir (Karagözoğlu, 2017).

Yapılan bazı çalışmalarda insan haklarının dünyada eğitim yoluyla korunabileceği, toplumlanın insanın gelişimi için spor eğitimine önem verdiği ve sporun eğitimin vazgeçilmez bir parçası olduğu ortaya konmuştur (Anın, 1991; Özbudun, 2007). Fakat yapılan literatür taramasında sporda insan hakları ile ilgili çok fazla çalışmaya rastlanmamıştır. Bu nedenle yapılan çalışmanın amac1; spor bilimleri fakültesinde eğitim gören öğrencilerin sporda insan haklarına ilişkin tutumlarının incelenmesidir. Felsefe, sosyoloji, temel hukuk, vatandaşlık, insan hakları ve demokrasi gibi dersler başta olmak üzere, daha birçok zorunlu ve seçmeli dersler gören bu öğrencilerin söz konusu hakları içselleştirme düzeylerini belirlemek önemlidir. Araştırma sonuçlarının bu boşluğu doldurması ve üniversitede insan hakları eğitimine ilişkin yapılacak etkinlik ve araştırmalara 1şık tutacağ1 düşünülmektedir.

\section{Yöntem}

Spor Bilimleri Fakültesi öğrencilerinin sporda insan haklarına ilişkin tutumlarını incelemek amacıyla yapılan bu araştırma tarama modeli niteliğindedir. Araştırmanın çalışma grubunu en az 1 yll spor geçmişine sahip, bireysel veya takım sporlarıla amatör ya da profesyonel olarak ilgilenmiş/ilgilenen, spor bilimleri fakültesi öğrencileri oluşturmaktadır. Araştırmaya katılan spor bilimleri fakültesi öğrencileri spor yöneticiliği $(n=149)$, antrenörlük eğitimi $(n=200)$ ve beden eğitimi ve spor öğretmenliği $(n=151)$ bölümlerinde öğrenim görmektedir. Çalışmaya 205’i kadın, 295’i erkek olmak üzere 500 öğrenci katılmıştır. Araştırmada verilerin toplanması amacıyla değişkenlerden (bölüm, sınıf, yaş, cinsiyet, branş, milli olma durumu, sporculuk düzeyi ve spor yaşı) oluşan bir bilgi formu oluşturulmuştur.

Verilerin toplanması amacıyla Sadık (2014) tarafindan geliştirilen, 3 alt boyut ve 29 maddeden oluşan 'Sporda İnsan Hakları Tutum Ölçeğgi kullanılmışırı. Alt boyutlar; 1. Kişilik Hakları, 2. Sosyal Haklar, 3. Dayanışma Hakları olarak belirlenmiştir. Ölçekten alınabilecek en düşük puan 29, en yüksek puan ise 145'dir. Sporda insan hakları tutum ölçeği kişisel haklar alt boyutu için alınabilecek en düşük puan 12 en yüksek puan 60, sosyal haklar alt boyutu için alınabilecek en düşük puan 9 en yüksek puan 45 ve dayanışma hakkı alt boyutu için alınabilecek en düşük puan 8 en yüksek puan 40 şeklindedir. Ölçeğin sıklık derecelendirmesinde 5'li likert tipi derecelendirme kullanılmıştır. Ölçeğin derecelendirmesi 'Tamamen Katılıyorum (1), Katılıyorum (2), Kararsızım (3), Katılmıyorum (4), Hiç Katılmıyorum (5)' şeklindedir. 
Bu çalısmada Sporda İnsan Hakları Tutum Ölçeği ve alt boyutları için güvenilirlik analizi uygulanmış, 9. soru güvenilirliği düşürdüğu için çıkartılmıştır. Sporda İnsan Hakları Tutum Ölçeği için güvenilirlik katsayısı 0.807 'dir. Ölçeğin alt boyutları için güvenilirlik katsayıları ise; Kişisel Haklar alt boyutu 0.743, Sosyal Haklar alt boyutu 0.739 ve Dayanışma Hakları alt boyutu 0.673 olarak hesaplanmıştır. Tüm güvenilirlik skorları 0,6'dan büyüktür bu nedenle güvenilirlik yeterlidir.

Değerlendirilmeye uygun 500 anket üzerinden istatistiksel analiz yapılmış olup hatalı veya eksik anketler çalş̧maya dahil edilmemiştir. Normal dağllım gösteren gruplar için ANOVA testi ve t testi, normal dağılım göstermeyen gruplar için ise Mann Whitney $U$ ve Kruskall Wallis $H$ testleri uygulanmıştır. Yapılan araştırmada anlamlılık düzeyi 0,05 olarak değerlendirmeye alınmıştır. Verilerin istatiksel değerlendirilmesinde SPSS 22.0 paket program kullanılmıştır.

\section{Bulgular}

Araştırmanın bu bölümünde sporda insan haklarına ilişkin tutumların ortalama, standart sapma ve istatiksel verileri aktarılmışır.

Tablo 1. Spor Bilimleri Fakültesi Ögrrencilerinin Sporda İnsan Haklarn Tutum Ölçeği Alt Boyutlarmmn Tanımlayıcı Istatistik. Sonuçlar

\begin{tabular}{|c|c|c|c|}
\hline Alt boyutlar & $n$ & $\bar{X}$ & $S S$ \\
\hline Kişisel Haklar & 500 & 17,26 & 4,96 \\
\hline Sosyal Haklar & 500 & 22,17 & 6,02 \\
\hline Dayanışma Hakları & 500 & 15,19 & 4,30 \\
\hline
\end{tabular}

Tablo 1 incelendiğinde, spor bilimleri fakültesi öğrencilerinin kişisel haklar alt boyutlarının $\bar{X}=17,26 \pm 4,96$, sosyal haklar alt boyutlarının $\bar{X}=22,17 \pm 6,02$, dayanışma hakları alt boyutlarının $\bar{X}=15,19 \pm 4,30$ ortalama ve standart sapmaya sahip oldukları görülmektedir.

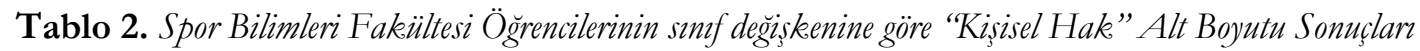

\begin{tabular}{|c|c|c|c|c|c|c|c|c|}
\hline & \multicolumn{6}{|c|}{ Kisisel Hak } & \multirow[b]{2}{*}{ Çoklu Karşılaştırmalar } & \multirow[b]{2}{*}{$P$} \\
\hline & $n$ & Medyan & $\overline{\bar{X}}$ & $S S$ & Min & Maks & & \\
\hline 1. sinif & 79 & 16,00 & 17,20 & 5,66 & 11,00 & 40,00 & \multirow{4}{*}{ 2. sinif-3. Sinif** } & \multirow{4}{*}{$0,012^{*}$} \\
\hline 2. sinif & 86 & 15,50 & 15,77 & 3,69 & 11,00 & 27,00 & & \\
\hline 3. sinif & 121 & 17,00 & 18,39 & 5,66 & 11,00 & 33,00 & & \\
\hline 4. sinif & 214 & 17,00 & 17,24 & 4,55 & 11,00 & 40,00 & & \\
\hline
\end{tabular}

Tablo 2'ye göre "Kişisel haklar" alt boyutunda sınıflar arası yapılan karşılaştırmada 2. ve 3. sınıflar arasinda anlamlı fark bulunmuştur $(\mathrm{p}<0,05)$.

Tablo 3. Spor Bilimleri Fakültesi Öğrencilerinin sinf değişkenine göre "Sosyal Hak" Alt Boyutu Sonuclar



"Sosyal Hak" alt boyutu için sınıflar arası yapılan karşılaştırmada 1. sınıf ve 4. sınıf ile 2. sınıf - 4. sınıf arasında anlamlı fark tespit edilmiştir $(\mathrm{p}<0,05)$ (Tablo 3).

Tablo 4. Spor Bilimleri Fakültesi Ögrencilerinin simf değgşkeenine göre "Dayanısma Hakkeı" Alt Boyutu Sonuclar

\begin{tabular}{|c|c|c|c|c|c|c|c|c|}
\hline & \multicolumn{8}{|c|}{ Dayanısma Hakkı } \\
\hline & $n$ & Medyan & $\overline{\boldsymbol{X}}$ & $S S$ & Min & Maks & Çoklu Karşılaştırmalar & $P$ \\
\hline 1. $\sin 1 f$ & 79 & 14,00 & 14,78 & 4,91 & 8,00 & 33,00 & & \\
\hline 2. sinif & 86 & 14,00 & 14,27 & 3,68 & 8,00 & 24,00 & 2. sinif $-3 \cdot \sin 1 f^{* *}$ & $0,026^{*}$ \\
\hline 3. sinif & 121 & 16,00 & 15,93 & 4,19 & 8,00 & 27,00 & & \\
\hline
\end{tabular}


ÇAVUŞOĞLU, KABADAYI, YILMAZ ve TAŞMEKTEPLİGİL

Spor Bilimleri Fakültesi Öğrencilerinin İnsan Haklarına Yönelik Tutumları

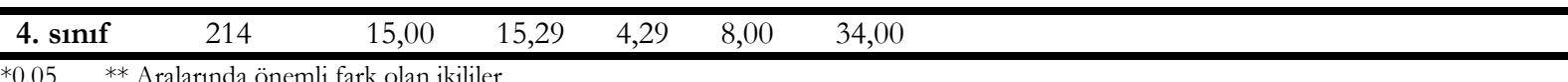

Tablo 4'te "Dayanışma hakkı" alt boyutunda sınıflar arası yapılan karşılaştırmada 2. ve 3. sınıflar arasinda anlamlı fark bulunmuştur $(\mathrm{p}<0,05)$.

Tablo 5. Spor Bilimleri Fakültesi Öğrencilerinin yaş değiskenine göre "Sosyal Hak" alt boyutu sonuclar

\begin{tabular}{|c|c|c|c|c|c|c|c|c|c|}
\hline & & \multicolumn{8}{|c|}{ Sosyal Hak } \\
\hline & & $n$ & Medyan & $\overline{\boldsymbol{X}}$ & $S S$ & Min & Maks & $\begin{array}{c}\text { Çoklu } \\
\text { Karş1laştırmalar }\end{array}$ & $P$ \\
\hline \multirow[b]{3}{*}{ Yaş } & $18-20$ & 167 & 22,00 & 21,20 & 6,10 & 9,00 & 39,00 & \multirow{3}{*}{$18-20-21-24^{* *}$} & \multirow{3}{*}{$0,010^{*}$} \\
\hline & $21-24$ & 312 & 23,00 & 22,53 & 5,86 & 9,00 & 38,00 & & \\
\hline & $\begin{array}{l}25 \text { ve } \\
\text { üzeri }\end{array}$ & 21 & 25,00 & 24,62 & 6,61 & 11,00 & 38,00 & & \\
\hline
\end{tabular}

Öğrencilerinin yaş değişkenine göre "Sosyal hak” skorlarına bakıldı̆̆ında 18-20 ve 21-24 yaş arasındaki gruplar arasında anlamlı farklılığa rastlanmıştır ( $\mathrm{p}<0,05)$ (Tablo 5).

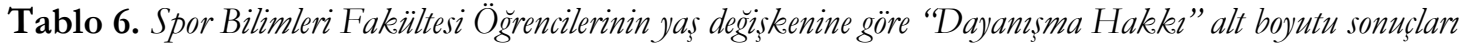

\begin{tabular}{|c|c|c|c|c|c|c|c|c|c|}
\hline & & \multicolumn{8}{|c|}{ Dayanısma Hakkı } \\
\hline & & $n$ & Medyan & $\overline{\boldsymbol{X}}$ & $S S$ & Min & Maks & Çoklu Karşılaştırmalat & $P$ \\
\hline \multirow{3}{*}{ Yaş } & $18-20$ & 167 & 15,00 & 14,51 & 4,06 & 8,00 & 33,00 & $18-20-21-24^{* *}$ & $0,045^{*}$ \\
\hline & $21-24$ & 312 & 15,00 & 15,50 & 4,39 & 8,00 & 34,00 & 18-20-25 ve üzeri** & \\
\hline & 25 ve üzeri & 21 & 16,00 & 16,05 & 4,21 & 8,00 & 23,00 & & \\
\hline
\end{tabular}

Tablo 6'ya göre yaş değişkeni açısından “Dayanışma hakkı" skorlarına bakıldığında 18-20 ile 21-24 yaş ve 18-20 ile 25 ve üzeri yaş grupları arasında anlamlı fark bulunmuştur $(p<0,05)$.

Tablo 7. Spor Bilimleri Fakültesi Öğrencilerinin bölüm değiskeenine göre "Dayanısma Hakekı" alt boyutu sonuclar

\begin{tabular}{|c|c|c|c|c|c|c|c|c|}
\hline \multirow{2}{*}{ Bölüm } & \multicolumn{8}{|c|}{ Dayanısma Hakk1 } \\
\hline & $n$ & Medyan & $\bar{X}$ & $S S$ & Min & Maks & Çoklu Karşılaştırmalar & $P$ \\
\hline Antrenörlük & 200 & 16,00 & 15,84 & 4,30 & 8,00 & 33,00 & & \\
\hline Spor Yöneticiliği & 149 & 15,00 & 15,18 & 4,14 & 8,00 & 34,00 & & \\
\hline $\begin{array}{l}\text { Beden Eğitimi } \\
\text { Öğretmenliği } \\
\text { (BEÖ) }\end{array}$ & 151 & 14,00 & 14,34 & 4,31 & 8,00 & 31,00 & BEÖ - Antrenörlük** & $0,003^{*}$ \\
\hline
\end{tabular}

Tablo 7'de "Dayanışma hakkı" alt boyutunda bölümler arası yapılan karşılaştırmada BEÖ ve Antrenörlük bölümleri arasında anlamlı fark bulunmuştur $(\mathrm{p}<0,05)$.

Tablo 8. Spor Bilimleri Fakültesi Öğrencilerinin milli olma durumuna göre "Sosyal Hak" alt boyutu sonuclar

\begin{tabular}{|c|c|c|c|c|c|c|c|c|}
\hline & & \multicolumn{7}{|c|}{ Sosyal Hak } \\
\hline & & $n$ & Medyan & $\bar{X}$ & $S S$ & Min & Maks & $P$ \\
\hline Milli Olma & Evet & 57 & 21,00 & 20,60 & 5,86 & 10,00 & 33,00 & $0037 *$ \\
\hline Durumu & Hayır & 443 & 23,00 & 22,37 & 6,01 & 9,00 & 39,00 & \\
\hline
\end{tabular}

*0,05

Öğrencilerinin milli olma durumuna göre "Sosyal hak" skorlarına bakıldığında milli olanlar ile olmayanlar arasında anlamlı farklılı̆ga rastlanmıştır (p<0,05) (Tablo 8).

Tablo 9. Spor Bilimleri Fakültesi Öğrencilerinin sporcu düzeyi değiskenine göre "Sosyal Hak" alt boyutu sonuçlar

\begin{tabular}{|c|c|c|c|c|c|c|c|c|}
\hline & \multicolumn{7}{|c|}{ Sosyal Hak } \\
\hline & & $n$ & Medyan & $\overline{\boldsymbol{X}}$ & $S S$ & Min & Maks & $P$ \\
\hline Sporcu & Amatör & 407 & 23,00 & 22,39 & 6,26 & 9,00 & 39,00 & $0,036^{*}$ \\
\hline
\end{tabular}




\begin{tabular}{llllllll}
\hline Düzeyi & Profesyonel & 93 & 21,00 & 21,22 & 4,71 & 10,00 & 35,00 \\
\hline$*_{0,05}$ & & & & & & & \\
\hline
\end{tabular}

Tablo 9'a göre sporcu düzeyi değişkeni açısından “Sosyal hak” skorlarına bakıldığında amatör ve profesyonel sporcular arasında anlamlı fark bulunmuştur $(\mathrm{p}<0,05)$.

\section{Tartışma, Sonuç ve Öneriler}

Bu çalışmanın amacını Spor Bilimleri Fakültesi öğrencilerinin 'Sporda İnsan Haklarına İlişkin 'Tutumlarının İncelenmesi’ oluşturmaktadır.

Sporda İnsan Hakları Tutum Ölçeği alt boyutları için tanımlayıcı istatistik sonuçlarına bakıldığında, spor bilimleri fakültesi öğrencilerinin sosyal haklar alt boyutu ortalamasının kişisel haklar ve dayanışma hakları alt boyutu ortalamasına oranla daha yüksek olmasına rağmen sporda insan haklarına ilişkin tutumlarının düşük olduğu görülmektedir (Tablo 1). Yapılan literatür araştırmasında ortaya konulan bazı çalşmalar bu sonuçlar ile paralellik göstermektedir. $\mathrm{Bu}$ araştırmalar öğretmenlerin demokratik davranışlarında eksiklikler olduğunu, sporcuların bazı durumlarda iç ve ya dış etkenlerden dolayı fair-play'e uymayan davranışlar sergilediğini ortaya koymaktadır (Gözütok, 1995; Şahin, 1995; Atasoy 1997, Yıldırım, 2017). Bu araştırma sonuçları öğretmen adayı olan spor bilimleri fakültesi ögrencilerinin sporda insan haklarına ilişkin tutumlarının düşük olmasını destekler niteliktedir. Fakat yapılan bazı çalışmalarda ise insan haklarına ilişkin tutumların yüksek olduğu sonucuna varılmıştır (Karaman-Kepenekçi, 1999; Çarıkçı ve Er, 2010; Karatekin vd., 2012; Dağ, 2013, Sadık, 2014). Özellikle Sadık (2014) tarafindan yapılan çalışmada araştırmaya katılan bireylerin frekans-yüzde dağılımı cinsiyet ve branş değişkeni açısından neredeyse birbiriyle eşit olmasına rağmen, sporda insan haklarına ilişkin tutumları bakımından farklılık göstermektedir. Bunun nedeninin ise bu araştırmanın çalısma grubunu hem aktif spor yapan hem de üniversiteler arası süper lig yarışmalarına takım sporları (basketbol, futbol, voleybol, hentbol) ve bireyler sporlarda (jimnastik, atletizm) katılan sporcu üniversite öğrencilerin oluşturması olduğu düşünülmektedir. Bu çalışmada ise araştırmaya katılan spor bilimleri fakültesi öğrencilerinin aktif spor yapması ve üniversite takımlarında yer alması şartı aranmamıştır. Üniversite takımlarına seçilen sporcuların ortaya koyacağı olumsuz tutumlar üniversiteler adına kötü imaj oluşturacağından, seçilen sporcuların her yönden değerlendirmeye alınarak seçilmesi araştırma sonuçlanını etkilemeye açı bir durum olarak karşımıza çıkmaktadır.

Sınıf değişkeni açısından kişisel haklar, sosyal haklar ve dayanışma hakları alt boyutlarında istatistiksel açıdan anlamlı fark bulunmuştur (Tablo 2, 3, 4). Çalışmaya 1. sınıf $(\mathrm{n}=79), 2$. sinıf $(\mathrm{n}=86), 3$. sinıf $(\mathrm{n}=121)$ ve 4. sınıf ( $\mathrm{n}=214)$ öğrencisi katılmıştır. 3. ve 4. sınıfların kişisel haklar, sosyal haklar ve dayanışma hakları alt boyutu skorları 1. ve 2. sınıflara göre daha yüksektir. İnsan Hakları ve Demokrasi dersi Spor Bilimleri Fakültesi'nin Spor Yöneticiliği ve Beden Eğitimi ve spor Öğretmenliği bölümlerinde iki ve dördüncü sınıfta okutulmaktadır. Dolayısıyla 1. Sınıf öğrencilerinin düşük puanlara sahip olması beklenen bir durumdur. Türkbay (2005) da yaptığı "Üniversite Öğrencilerinin Demokratik Tutum ve Değerleri Üzerine Bir Araştırma' isimli çalışmasında üniversite dördüncü sınıf öğrencilerinin birinci sınıflardan; daha demokrat olduğu varsayımına ulaşmışırı. Ayrıca Yeşil (2004) İnsan Hakları ve Demokrasi Eğitiminde Yöntem' adlı çalışmasında insan hakları eğitiminin önemli olmasının yanında davranış boyutunun daha önemli olduğunu ortaya koymuştur. Antrenörlük bölümünde insan hakları ve demokrasiye ilişkin ders olmasa da yüksek öğrenimin sağladığ1 sosyal kültürel çevrenin bireylerin haklarından yararlanma durumlarına katkı sağladığı söylenebilir. Sporda insan hakları alt boyutları için alınan skorların 1. ve 2 . sınıflar için daha düşük olup 3 ve 4. sınıflar için daha yüksek olmasi; üniversiteye yeni gelen öğrencilerin insan hakları bilgi ve davranışlarında eksiklik oluşu ve 1. ve 2. sınıflarda üniversite eğitimleri ile beraber yaşadıkları kültür ortamından etkilenerek insan haklarına ilişkin bilgi ve davranışlarının gelişmesi sonucu 3. ve 4. sinıflarda daha iyi duruma geldikleri şeklinde açıklanabilir.

Yaş değişkeni açısından kişisel haklar alt boyutunda istatistiksel açıdan anlamlı fark bulunmazken, sosyal haklar ve dayanışma hakları alt boyutlarında istatistiksel açıdan anlamlı fark bulunmuştur (Tablo 5, 6). Çalışmaya 18 ve 20 yaş arası 167, 21 ve 24 yaş arası 312, 25 ve üzeri yaşında ise 21 kişi olmak üzere toplamda 500 kişi katılmıştır. Sosyal haklar ve dayanışma hakları alt boyutları için 25 ve üzeri yaş grubunun skorları, 18 ve 20 yaş arası grup ile birlikte 21 ve 24 yaş arası gruba göre daha yüksektir. 21 ve 24 yaş arası grubun aldıkları skorlar ise, 18 ve 20 yaş arası gruba göre daha yüksektir. Bu sonuçlar yaş grubu arttıkça alınan skorların arttığını ortaya koymaktadır. En düşük skora sahip yaş grubunun en düşük yaş aralı̆ı̆na sahip olan 18 ve 20 yaş arası grup olduğu görülmektedir. Bu durum Atalay (2016) tarafindan yapılan 
'Türkiye'de Üniversitelerde Eğitim Gören Öğrenci-Sporcuların Ahlaki Karar Alma Tutumları' adlı çalışma ile paralellik göstermektedir. Sporda insan hakları alt boyutları için alınan skorların yaş grubu arttıkça artması tecrübe ve olgunlaşma ile açıklanabilir. Karşılaşılan durumlardan ders çıkarma ve hatalarını düzeltme eğiliminin spor bilimleri fakültesi öğrencilerinin aldıkları skorları olumlu yönde etkileyebileceğini düşündürmektedir. Yaş grubu arttıkça alınan eğitim ve gerçekleşen kazanımların da artacağı düşünülürse bireylerin insan hakları tutumlarında artış gözlenebilmesi olağan bir durum olarak karşımıza çıkmaktadır.

Bölüm değişkeni açısından kişisel haklar ve sosyal haklar alt boyutlarında istatiksel açıdan anlamlı fark bulunmazken dayanışma hakları alt boyutunda istatiksel açıdan anlamlı fark bulunmuştur (Tablo 7). Antrenörlük bölümü öğrencilerinin dayanışma hakları alt boyutu skorları spor yöneticiliği ve beden eğitimi öğretmenliği bölümü öğrencilerine göre daha yüksektir. Esasında antrenörlük bölümü öğrencilerinin insan hakları ve demokrasi dersini almayan tek bölüm olmasına rağmen puanlarının yüksek çıkması şașırtıcı bir sonuç olarak görülmektedir. Fakat anlamlı farkın dayanışma hakları alt boyutunda çıkması Yıldııı (2017) tarafindan yapılan çalışmada sporcuların sporda fair-play ahlakında olmayı öğrenmelerinin en büyük etkisinin kendi karakteri ve antrenör etkisi sayesinde olduğu sonucu ile açıklanabilir. Antrenörlerin sporcular için bir rol model olmasıyla birlikte sporcuların sporun birleştirici gücünü kavraması ve ahlaki kazanımlarını öğrenmesini sağlayan ve geliştiren en etkili araç oluşu da antrenörlük bölümü öğrencilerinin dayanışma hakkı skorlarının diğer bölüm öğrencilerine göre daha yüksek oluşunu açıklar niteliktedir. Gömleksiz ve Çetintaş’ın (2011) yaptıkları "Öğretmen Adaylarının Demokratik Tutumları" isimli çalışmada, öğretmen adaylarının demokratik tutumlarının, bölüm değişkeni açısından farklılaştığını tespit etmiștir. Ayrıca Sadık (2014) tarafından yapılan çalıșmada dayanışma hakları alt boyutunda istatiksel açıdan anlamlı fark bulunmamasına rağmen antrenörlük bölümü öğrencilerinin öğretmenlik bölümü ve diğer bölüm öğrencilerine göre dayanışma hakları alt boyutu skorlanının daha yüksek olması çalışma sonucunu desteklemektedir. Diğer taraftan Türkbay (2005) yaptı̆̆ "Üniversite Öğrencilerinin Demokratik Tutum ve Değerleri Üzerine Bir Araştırma' isimli çalışmasında öğrencilerin demokratik tutum ve değerlerinin eğitim, temel bilim alanları, cinsiyet, aile, meslek, yerleşim yeri gibi pek çok ekonomik, toplumsal değişkenin etkisine bağıı olarak değiştiğini ve hiçbir değişkenin tek basına etkili olmadığını ortaya çıkarmıştır.

Milli olma durumu değișkeni açısından kișisel haklar ve dayanıșma hakları alt boyutunda istatiksel açıdan anlamlı fark bulunmazken, sosyal haklar alt boyutunda istatiksel açıdan anlamlı fark bulunmuştur (Tablo 8). Çalsşmaya 57 milli sporcu ve 443 milli olmayan sporcu olmak üzere toplam 500 öğrenci katılmıştır. Milli olmayan sporcuların milli sporculara göre sosyal haklar alt boyutu skorları daha yüksektir. Tanrıverdi (2012) tarafindan yapılan 'Spor Ahlakı ve Şiddet' adlı çalışmada sporun; şampiyonluklar kazanma, ünlü ve popüler olma, mensubu olduğu toplumun ya da 1 rkın diğer toplumlara üstünlüğunnü gösterme amaciyla yapılan bir aktiviteye dönüştüğü ortaya koyulmuştur. Bu sonuç ve değerlendirme, çalışmaya milli sporcuların milli olmayan sporculara göre sosyal haklar skorlarının düşük olmasını destekler niteliktedir. Milli olmayan sporcuların sporu rekabet amaçlı yapmamış olması gibi etkenler spor bilimleri fakültesi ögrencilerinin sporda insan hakları sosyal haklar alt boyutundan daha yüksek puan almasını sağlayacak neden olarak karşımıza çıkmaktadır.

Sporculuk düzeyi değişkeni açısından kişisel haklar ve dayanışma hakları alt boyutunda anlamlı fark bulunmazken, sosyal haklar alt boyutunda istatiksel açıdan anlamlı fark bulunmuştur (Tablo 9). Çalışmaya 407 amatör ve 93 profesyonel sporcu olmak üzere toplamda 500 öğrenci katılmıştır. Amatör sporcuların sosyal haklar alt boyutu skorları profesyonel sporculara göre daha yüksektir. Tanriverdi (2012) tarafindan yapılan 'Spor Ahlakı ve Şiddet' adlı çalısmada sporun; aslında oyun ve sportif amaçlı bir aktivite olmasının yanında rekor kırma ve kazanç sağlama gibi amaçlar yüklendiği ve bu amaçlarla yapıldığı da ortaya konmuştur. Bu iddia çalısmaya katılan spor bilimleri fakültesi amatör sporcu öğrencilerinin sosyal haklar alt boyutu skorlarının profesyonel sporcu öğrencilerinden daha yüksek olmasını destekler niteliktedir. Amatör sporcularda spora katılımın, bireyin fiziksel ve ruhsal yönden sağlıklı olmasının yanında hayatına sosyallik katmak gibi öncelikleri bulunmaktadır. Profesyonel olarak yapılan sporlarda ise birincil amaç kazanç sağlamaktır. Geçimini buradan sağlayan bireylerin bazı iç ve dış etkenler ile birlikte olumsuz tutum ve davranışlarda bunalabileceği ve bu nedenle insan haklarına ilişkin tutumlarında eksiklik oluşabileceği düşünülmektedir.

Sonuç olarak bu çalısmada sporcu üniversite örgencilerinin kişilik hakları, sosyal haklar ve dayanışma hakları alt boyutlarına yönelik tutumları saptanmıştır. Sporcuların sporda insan haklarına yönelik tutumlarının olumsuz nitelikte olduğu söylenebilir. Kişilik hakları ve dayanışma hakları boyutlarında tutum puanlarının düşük, sosyal haklar boyutunda ise yüksek olduğu görülmüştür. 


\section{Kaynakça}

Anın, A.C. (1991). Türkiye'de cumhuriyet devrinde beden eğitimi öğretmeni yetiştirme çalışmaları ve aşamaları. Spor ve Bilim Dergisi, 1.

Atalay, A. (2016). Türkiye'de üniversitelerde eğitim gören öğrenci-sporcuların ahlaki karar alma tutumları. Akademik Sosyal Arastermalar Dergisi, 4(31), 53-66.

Atasoy, A. (1997). Ilkë̈gretim ikinci kademede demokrasi eğitimi ve ilkögretim ikinci kademe ögretmen ve ögrencilerin demokratik tutum ile davranıslarmm karșılaștırmalı olarak incelenmesi (Yüksek Lisans Tezi). Ankara Üniversitesi Sosyal Bilimler Enstitüsü, Ankara.

Aycan, N. (2002). Sağhlk yükesekokullar için sağhle sosyolojisi. Manisa: Manisa Celal Bayar Üniversitesi Yüksek Öğrenim Vakfi.

Berktay, F. (2004). Kadınlarn insan haklarmm gelişimi ve Türkiye. Sivil Toplum ve Demokrasi Konferans Yazıları, İstanbul Bilgi Üniversitesi Sivil Toplum Kuruluşları Eğitim ve Araştırma Birimi, 7.

Çarıkçı, S. ve Er, K.O. (2010). Balıkesir Üniversitesi Necatibey Eğitim Fakültesi'nde öğrenim gören öğretmen adaylarının insan hakları eğitimine yönelik tutumları. Bahkesir Üniversitesi Sosyal Bilimler Enstitüsü Dergisi, 13(24), 54-69.

Dağ, N. (2013). Simf ögretmeni adaylarmm insan haklarma ilişkin tutumlarm etkileyen faktörler (Doktora Tezi). Gazi Üniversitesi Eğitim Bilimleri Enstitüsü, Ankara.

Gömleksiz, M. N. ve Çetintaş S. (2011). Öğretmen adaylarının demokratik tutumları, Dicle Üniversitesi Ziya Gökalp Eğitim Fakültesi Dergisi, 17, 1-14.

Gözütok, D. (1995). Öğretmenlerin demokratik tutumlar. Ankara: Türk Demokrasi Vakfi Yayınları.

Gül, F. (2013). Bir değer olarak insan hakları ve insan hakları bilincinin gelişiminde demokrasinin rolü. Mubafaz̧akâr Düsünce, 9(36), 67-75.

Karagözoğlu, N. (2017). İnsan hakları eğitiminde gazetelerden yararlanma. Abi Evran Üniversitesi Kirşehir Eŭitim Fakültesi Dergisi, 18(3).

Karaman,-Kepenekçi Y. (1999). İnsan hakları eğitiminde okul ve sınıf havasının rolü. Kuram ve Uygulamada Ĕ̈itim Yönetimi Dergisi, 19, 353-361.

Karatekin, K., Merey, Z., Sönmez, Ö.F., ve Kus, Z. (2012). Sosyal bilgiler öğretmen adaylarının insan haklarına yönelik tutumları. International Periodical for the Languages, 7(4, 2193-2207.

Kepenekçi, Y. (2000). Türkiye'de genel ortaögretim kurumlarnda insan haklar eğitimi (Yüksek Lisans Tezi). Ankara Üniversitesi Sosyal Bilimler Enstitüsü, Ankara.

Kuçuradi, İ. (2007). Insan hakelar kavram ve sorunlar. Ankara: TFK Yayınları.

Memduhoğlu, H. B. (2008). Örgütsel sosyalleşme ve türk eğitim sisteminde örgütsel sosyalleşme süreci. Yü̃üncü Yıl Üniversitesi Ë̆itim Fakültesi Dergisi, 5(2), 137-153.

Meşeci, F. (2008). Öğretmenin sosyalleştirici rolü ve istenmeyen davranışlarla başa çıkma. Hasan Ali Yücel Ĕgittin Fakültesi Dergisi, 1, 115-125.

Özbudun, E. (2007). Democratization reforms in Turkey, 1993-2004. Turkish Studies, 8(2), 179-196.

Sadık, R. (2014). Sporcularn sporda insan haklarna iliskin tutumlarmm incelenmesi (Doktora Tezi). Abant İzzet Baysal Üniversitesi Sosyal Bilimler Enstitüsü, Bolu.

Şahin, A. Ç. (1995). Illköğretim okullarnda yönetimin demokrasi ve otokrasi boyutlar arasındaki yeri (Yüksek Lisans Tezi). Ankara Üniversitesi Sosyal Bilimler Enstitüsü, Ankara.

Şahin, İ. (2009). Demokrasi ve insan hakları eğitimi. e-Journal of New World Sciences Academy Education Sciences, 4(4), 1341-1354.

Tanrıverdi, H. (2012). Spor ahlak1 ve şiddet. The Journal Of Academic Social Science Studies, 5(8), 1071-1093.

Tepe, H. (2009). Sosyal haklar ve insan haklar1: sosyal ve ekonomik haklar olmadan insan haklar1 korunabilir mi? http://www.sosyalhaklar.net/2009/bildiri/tepe.pdf (28/04/2017).

Topsakal, C. (2017). Ödev kavramı açısından yaşam hakkı. TURAN: Stratejike Araștırmalar Merkę̧i, 9(36), 401-408.

Türkbay, R. A. (2005). Üniversite Öğrencilerinin Demokratik. Tutum ve Değerleri Üzerine Bir Arastırma (Yüksek lisans tezi), Denizli: Pamukkale Üniversitesi Eğitim Bilimleri Enstitüsü.

Ünal, Ş. (1994). İnsan haklarının tarihi, felsefi ve hukuki temelleri. Ankara Barosu Dergisi, 1, 41-74.

Yeşil, R. (2004). İnsan hakları ve demokrasi eğitiminde yöntem. Gaži Üniversitesi Kırşebir Eğitim Fakültesi Dergisi, 5(1).

Yıldırım, M. (2017). Üniversitelerde okul ve kulüp takımlarında oynayan sporcuların sporda fair-play anlayışlarının belirlenmesi (Eskişehir Osmangazi Üniversitesi Örneği). İnönü Üniversitesi Beden Eğitimi ve Spor Bilimleri Dergisi, 4(1),01-15.

Yiğittir, S. (2013). Temel insan hak ve özgürlükleri. İçinde İsmail Acun vd. (Ed.), İnsan Haklar, Demokrasi ve Vatandaşlık Ë̆itimi (ss. 1-14). Ankara: PegemA.

Yüksel, M. (2007). İnsan haklarının sosyo-tarihsel temelleri. İnsan Haklar Yillğg, 25, 1-19. 


\section{EXTENDED ABSTRACT}

An individual's being aware of his/her right, defending his/her rights through suitable ways and methods when necessary and watching out and defending other people's rights when necessary are attainments that can occur with effective human rights education (Karagözoğlu, 2017). For this reason, the aim of the present study is to examine the attitudes of students studying in sport sciences faculty about human rights in sport. It is important to find out to what extent students who receive a great number of compulsory and elective courses, especially philosophy, sociology, basic law, citizenship and democracy internalise these rights. It is thought that the results of the study will fill in this gap and shed a light on activities and researches to be conducted in university about human rights education.

The research group of the study consists of students of coaching department (n:200), sport management department (n:149) and physical education teaching department (n:151) who had at least one year of sport experience, who was doing/did individual or team sports professionally or as an amateur. In the study, an information form consisting of variables (department, year of study, age, gender, branch, being on the national team, sportiveness level and sport age) and "Human rights in sport scale" developed by Sadik (2014) which consisted of 3 sub-dimensions and 29 items were used. The sub-dimensions were 1 . Personality rights, 2. Social rights, 3. Cooperation rights. The lowest point one can get from the scale is 29 , while the highest point is 145 . The lowest score one can get from personal rights sub-dimension of human rights in sport attitude scale is 12 , while the highest score is 60 ; the lowest score one can get from social rights sub-dimension is 9 , while the highest score is 45 and the lowest score one can get from cooperation rights sub-dimension is 8 , while the highest score is 40 . In the present study, the students were given Human rights in sport attitude scale and reliability analysis was performed for sub-dimensions and ninth question was excluded because it caused reliability to decrease. Reliability coefficient for Human rights in sport attitude was 0.807 . Statistical analyses were conducted from 500 questionnaire forms suitable for assessment and forms which had missing or wrong information were not included in the study. Mann Whitney $\mathrm{U}$ and Kruskall Wallis $\mathrm{H}$ test were used for groups which were not normally distributed. Significance level was taken as 0,05 .

In terms of the comparison of study years, significant differences were found in "personal rights" sub-dimension between students in their second year of study and those in their third year; in "social rights" sub-dimension between students in their first year of study and those in their fourth year and between students in their second year of study and those in their fourth year; and in "cooperation rights" sub-dimension between students in their second year of study and those in their third year $(p<0.05)$. When students' "social rights" scores were examined in terms of the variable of age, significant difference was found between age groups of 18-20 and 21-24; while significant difference was found between age groups of $18-20$ and $21-24$ and $18-20$ and 25 and older $(\mathrm{p}<0.05)$ in "cooperation rights" sub-dimension. In comparisons between departments, significant differences were found between students of physical education teaching and coaching in "cooperation rights" sub-dimension $(p<0.05)$. When students" "social rights" scores were examined in terms of the variable of playing in the national team, significant difference was found between students who were in the national team and those who were not $(p<0.05)$. In addition, when "social rights" scores were examined in terms of the variable of athlete level, significant difference was found between students who were amateur and those who were professional $(\mathrm{p}<0.05)$. In general, the scores taken for the sub-dimensions of human rights in sport were found to be lower for students who were in their first and second years, while they were found to be higher for students who were in their third and fourth years. In addition, it was concluded that scores taken increased as age group increased. The age group with the lowest score was found to be the age group between 18 and 20 years of age.

As a conclusion, attitudes of athlete university students towards the sub-dimensions of personal rights, social rights and cooperation rights were found in the present study. Although average social rights sub-dimension scores of sports faculty students were found to be higher when compared with personal rights and cooperation rights sub-dimensions, general attitudes about human rights in sport were found to be low. Thus, it was concluded that that there is need for a great number of social and educational regulations in Turkey. 